L.S. Namazova-Baranova ${ }^{1}$ M.S. Kotlyarova ${ }^{1}$, Y.V. Rovenskaya ${ }^{1}$, V.P. Vavilova ${ }^{2}$, G.A. Novik ${ }^{3}$, O.P. Kovtun ${ }^{4}$, N.I. Averyanova ${ }^{5}$, A.N. Galustyan ${ }^{3}$, N.A. Ilyenkova ${ }^{6}$, A.I. Safina $^{7}$, Y.V. Lobzin ${ }^{8}$, M.A. Snovskaya ${ }^{1}$

1 Scientific Center of Children's Health, Moscow, Russian Federation

2 Kemerovo State Medical Academy of the Ministry of Health, Russian Federation

3 Saint Petersburg State Pediatric Medical University of the Ministry of Health, Russian Federation

4 Ural State Medical University of the Ministry of Health, Ekaterinburg, Russian Federation

5 Wagner Perm State Medical Academy of the Ministry of Health, Russian Federation

6 Territorial clinical hospital, Krasnoyarsk, Russian Federation

7 Kazan State Medical Academy of the Ministry of Health, Russian Federation

8 Research institute of pediatric infections of the Federal Biomedical Agency, Saint Petersburg, Russian Federation

\title{
Comparative analysis of effectiveness and safety of phyto- and antibiotic therapy of acute bronchitis in children: results of a multicenter double blind randomized clinical trial
}

\section{Author Affiliation:}

Leyla Seymurovna Namazova-Baranova, correspondent member of the Russian Academy of Medical Sciences, Professor, MD, PhD, deputy head of the Scientific Center of Children's Health for science, head of the research institute of preventive pediatrics and medical rehabilitation of the Scientific Center of Children's Health

Address: 2/1 Lomonosovskiy Av., Moscow, 119991; tel./fax: +7 (499) 783-27-93; e-mail: namazova@,nczd.ru

\section{Article received: 11.07.2014. Accepted for publication: 17.09.2014.}

Although viruses cause most cases of acute bronchitis, antibacterial drugs are still widely used to treat children with such diseases; this results in development of antibiotic resistance. Therefore, one of the key objectives of clinical medicine is now an effort to reduce unreasonable use of antibacterial agents. A multicenter double blind randomized clinical trial (E-BRO-PCT) involved 182 2-6-years-old children and was aimed at assessing effectiveness and safety of phytotherapy (the syrup characterized by a fixed combination of thyme herb and ivy leaf extracts) of acute bronchitis. Patients were divided into groups according to the type of therapy: phyto-, antibacterial or multimodal therapy. The level of procalcitonin (PCT) - a bacterial inflammation marker - was measured retrospectively in the blood samples of all the children obtained at inclusion to the study. Therapy effectiveness was assessed by means of overall assessment of response to treatment on day 7. The share of children with low PCT and positive response to phytotherapy was comparable to the share of children subjected to antibiotic therapy. This is also true for all the patients included in the study regardless of the PCT level. Phyto- and antibacterial therapy featured a comparable safety profile; however, according to the researchers, the former one came out slightly better. Results of this study convincingly demonstrate that phytotherapy is an effective and well-tolerated type of treatment of acute bronchitis in children.

Keywords: phytotherapy, phytogenic drug, antibiotic therapy, acute bronchitis, procalcitonin, procalcitonin level assay, children, thyme herb and ivy leaf extracts.

\section{INTRODUCTION}

Acute bronchitis (ICD-10: J20) is an infectious inflammatory disease of lower airways observed at any age; the most susceptible populations are children and the elderly. $\mathrm{Ca} .90 \%$ of all the acute bronchitis cases are caused by viruses [1]. Inflammation is characterized by bronchial mucosal edema and hyperemia. Excessive seromucous bronchial secretion excretion might be observed in 
the event of bronchitis accompanied by productive cough. In most cases, clinical and biochemical blood assays do not detect any characteristic deviations. The main symptom of acute bronchitis is non-productive (dry) or productive (with phlegm) cough.

The main objective of treating acute bronchitis with productive cough is promotion of expectoration by means of, among other things, mucoactive drugs. The general therapy objective is to alleviate symptoms, reduce disease duration and prevent development of bacterial infections and such complications as pneumonia.

Although acute bronchitis is usually virus-induced, antibiotics are widely used for acute bronchitis therapy $[2,3]$. According to A.C. Nyquist et al., $75 \%$ of the children with bronchitis are prescribed antibiotics [4]. Ca. 86.6\% families in Russia use antibiotics at their discretion: in most cases, such self-treatment is observed in the event of acute respiratory infections and cough [5]. A.L. Hersh et al. also confirm that more than $70 \%$ of the patients in the US outpatient practice for respiratory diseases (especially for acute infections) undergo antibacterial therapy; the authors emphasize that broad-spectrum antibiotics are often prescribed unreasonably - for the conditions, antibiotic treatment whereof is extremely unlikely to produce good results [6]. Consequences of excess antibiotic use are well known; the worst is development of bacterial resistance to antibiotics, which is an urgent problem for many countries, including Russia [7]. Thus, decrease in unreasonable antibiotic use, especially in children, is crucial $[4,6,8]$. In 2004, M. Christ-Crain et al. published a study, wherein serum procalcitonin (PCT) was analyzed as a marker of bacterial infections of lower airways [9]. Functional sensitivity of this method is $0.06 \mathrm{ng} / \mathrm{ml}$. According to this study, low serum PCT $(<0.25 \mathrm{ng} / \mathrm{ml})$ identifies patients without bacterial infections, i.e. the patients, who do not need antibacterial drugs. However, this method has not yet gained wide spread in outpatient practice in Russia.

Phytotherapy has been used in medical practice for decades. Eucalyptus and rosemary oils, balsam of Peru, plantain, thyme herb and ivy leaf extracts are among the many active components making part of drugs for bronchitis. Syrup Bronchipret (Bionorica CE, Germany; certificate of registration No. LS-000181 of 15.04.2005, 05.04.2010) with a fixed combination of thyme herb and ivy leaf extracts is used as an expectorant for treating acute and chronic inflammatory respiratory diseases characterized by cough and phlegm discharge (tracheitis, tracheobronchitis, bronchitis).

This study was designed both to compare effectiveness of phytotherapy and antibiotic therapy (amoxicillin, granules) and optimize treatment of children with acute bronchitis, who do not need antibiotics, identified on the basis of PCT. Amoxicillin was selected due to the fact that the bacterial strains causing complications of respiratory infections are extremely sensitive to penicillin antibiotics.

\section{PATIENTS AND METHODS}

The study was performed at 9 active Russian research centers (June 2011 - June 2012) in compliance with provisions of the Declaration of Helsinki and guidelines for Good Clinical Practice of the International Conference on Harmonization of Technical Requirements for Registration of Pharmaceuticals for Human Use (ICH-GCP). The study was approved by the Russian Federal Service on Surveillance in Healthcare, Ethics Committee of the Russian Federal Service on Surveillance in Healthcare and local ethics committees of all the centers. Written informed consent was obtained from parents or legal representatives of all the study subjects.

The study involved outpatients - 2-6-years-old boys and girls diagnosed with acute bronchitis characterized by productive cough lasting for not more than 2 days by the time of inclusion. Other inclusion criteria were single increase in axillary temperature $>38.0{ }^{\circ} \mathrm{C}$ within 2 days prior to the study and leukocyte count $<15 \times 10^{9} / 1$. Demographic and other initial parameters are given in tb. 1.

Exclusion criteria were febrile convulsions, acute tonsillitis / acute otitis media, obstruction episodes, pneumonia, pertussis, tuberculosis, mucoviscidosis, other secondary acute infections of non-respiratory organs and systems, as well as documented HIV infection, acute hepatitis / 
serological markers of acute hepatitis, signs or symptoms of severe, progressive or uncontrollable renal, hepatic, gastrointestinal, circulatory, endocrinal, cardiovascular, respiratory or nervous systems. Other exclusion criteria were high sensitivity to active components or adjuvants of the drugs used in the study contraindications against amoxicillin use, the conditions inducing increase in the PCT level (such as traumas and invasive mycosis), specific previous therapy (see below) and participation in other clinical studies within 6 weeks prior to this study. Study design: multicenter double-blind, double-controlled study with active control in parallel groups in order to compare effectiveness and safety of different treatment types: phytotherapy (group 1), antibiotic therapy (group 2) and multimodal (phytopreparations + antibiotics) therapy (group 3). The patients satisfying all the inclusion criteria were randomized (1:1:1) to three therapy groups (tb. 2). The study employed the double-dummy method: along with the active drug form appropriate placebos were additionally used in groups of phytotherapy and antibiotic therapy. Concomitant therapy with such drugs as immunosuppressants, glucocorticoids, immunomodulators, vaccines, broncholytic agents, $\beta_{2}$-adrenomimetic agents, antitussive agents, antibiotics and other phytopreparations was not allowed.

The expected study duration for each patient was 28 days -10 therapy days ( 7 in the event of early recovery of a patient according to the researcher's estimates) and 18 follow-up days (pic. 1). Blood sampling was performed in the course of the first visit in order to measure leukocyte count (inclusion criterion) and the initial PCT level. Taking into account results of a study performed by M. Christ-Crain et al. [9], the PCT level was chosen as a criterion for dividing patients into two subgroups: with (PCT $\geq 0.25 \mathrm{ng} / \mathrm{ml}$ ) and without symptoms of bacterial infections $(\mathrm{PCT}<0.25 \mathrm{ng} / \mathrm{ml})$.

\section{Evaluation methods}

Researchers evaluated general response to therapy on a 1-4 scale after 7 and 10 days of treatment. Additional effectiveness evaluation was performed by the patient's parents, who recorded their assessments of the child's overall condition, his/her ability to lead a normal everyday lifestyle, ability to fall sleep undisturbed, nocturnal sleep disturbances, nocturnal cough in a diary. Researchers and parents evaluated tolerance to the used drugs in the end of the therapy. Parents/researchers registered all the adverse events in the course of observation.

\section{Statistical analysis}

Effectiveness parameters were evaluated using data of the patients who completed the study without significant deviations from the protocol (per protocol population, PP). Safety parameters were evaluated in all the randomized patients who received at least one drug dose and who provided sufficient safety data (safety evaluable population, SEP).

The study was primarily aimed at demonstrating phytotherapy non-inferiority to antibiotic therapy by day 7 . Farrington-Manning test was utilized for this purpose; the maximum allowable limit $(\Delta)$ was -0.15 in the PP group. Sensitivity analyses were performed for each study center taking into account the patient's age. Analysis of response to therapy on day 10 was similarly used as a secondary effectiveness endpoint. Fisher's exact test was utilized to analyze several parameters: difference in the share of patients responding to therapy in group of multimodal and antibiotic therapy; patients withdrawn from the study and receiving a different antibiotic; patients with continued or resumed acute bronchitis; patients with low PCT responding to therapy as compared to such patients with high PCT. Covariance analysis was used to treat the patient's overall condition parameters and parental evaluation of response to therapy. Parameters "time to the event" were analyzed using the Kaplan-Meier method and the log-rank test. Wilcoxon test was used to calculate the share of patients responding to therapy. Differences regarding tolerance to the used drugs between the three therapy groups were analyzed by means of the Kruskal-Wallis test. Paired tests intended to compare therapy groups were performed sing the Wilcoxon test. 


\section{RESULTS}

The study involved 182 2-6-years-old boys and girls diagnosed with acute bronchitis characterized by productive cough. Study population was a representative sample of children with acute bronchitis (pic. 2 demonstrates the number of randomized patients, treated patients and the children who completed the study and were included in analysis of the results).

\section{Effectiveness}

According to the researcher's estimates, the share of patients responding to therapy in subgroups of patients with PCT $<0.25 \mathrm{ng} / \mathrm{ml}$ (149 out of $158 ; 94.3 \%)$ was the same in all the three groups (97.8, 98.1 and $98.0 \%$, respectively) after 7 therapy days (primary endpoint).

As effective as antibiotic therapy in group 2, phytotherapy in the group 1 patients responding to therapy was indicated both for the subgroup of patients with low PCT $(<0.25 \mathrm{ng} / \mathrm{ml})$ and all patients after 7 therapy days. The difference in response to therapy between groups 1 and 2 was not statistically significant. Non-inferiority $p$ value was statistically significant (low PCT: $p=0.0041$; all patients: $p=0.0024)$; lower limit of the $95 \%$ confidence interval (CI) was above the non-inferiority limit (low PCT: $-11.19 \%$; all patients: $-10.48 \%$; pic. 3 ).

Phytotherapy non-inferiority to antibiotic therapy of children in appropriate groups was also demonstrated after 10 therapy days.

Comparison of response to therapy in groups 3 and 2 did not demonstrate significant differences after 7 and 10 therapy days. Primary endpoint's sensitivity analysis did not reveal differences in response to therapy associated with specific study sites and age of patients.

No statistically significant differences were observed between phytotherapy and antibiotic therapy regarding secondary endpoints according neither to the researcher's estimates (withdrawal from the study and need in a different antibiotic, continued or resumed post-therapy bronchitis, post-therapy recovery) nor to the parental estimates (patient's overall condition, time to return to normal everyday lifestyle, time to the first undisturbed falling sleep, to disappearance of nocturnal sleep disturbances and nocturnal cough, response to therapy).

However, several insignificant differences between therapy groups are worth mentioning. Thus, the average time to return to the normal everyday lifestyle in the subgroup of patients with low PCT (4.0; 5.0 and 5.0 days) and disappearance of nocturnal cough (4.0; 6.0 and 6.0 days) was shorter in the phytotherapy group (44 patients) than in the antibiotic therapy (47 patients) and multimodal therapy (48 patients) groups, respectively. Apparently, phytotherapy was more effective than antibiotic therapy, whereas multimodal therapy (phytotherapy enhanced with antibiotics) did not result in higher effectiveness (tbs. 3, 4). In groups 1 and 2 patients with high PCT ( 5 and 2 patients, respectively) required a longer median time to return to normal everyday lifestyle, undisturbed falling asleep, absence of sleep disturbances and nocturnal cough than the multimodal therapy group patients. In this group, the average time to the event in the high PCT subgroup (2 patients) was the same or shorter than in the low PCT subgroup (48 patients) (see tbs. 3,4$)$; this indicates a certain degree of synergy between antibiotic activity and phytotherapy in the event of acute bacterial bronchitis.

The share of patients responding to therapy did not depend on the PCT level and was equally high in all the therapy groups. The expected lower effect of antibiotic therapy in the subgroup of patients with low PCT (indicating virus infection) as compared to the subgroup of patients with high PCT (bacterial infection marker) was not convincingly confirmed for this parameter. Only 2 patients from the low PCT subgroup discontinued the treatment and started to receive a different antibiotic: one patient $(2.2 \%)$ discontinued phytotherapy, another (1.9\%) - antibiotic therapy.

\section{Safety}

Phytotherapy (herbal syrup characterized by thyme herb and ivy leaf extracts) and antibiotic therapy (amoxicillin) had comparable safety profiles; however, researchers were in favor of phytotherapy. 
The number of patients reporting at least one adverse event was the same between the groups of phytotherapy ( 7 out of 62 patients reported 7 events) and antibiotic therapy ( 6 out of 60 patients reported 7 events). Only 2 out of 59 patients reported 2 adverse events in the multimodal therapy group. In the course of treatment, 12 out 181 patients $(6.6 \%)$ reported at least one adverse event. Rhinitis ( 7 patients) was the most common adverse events: it was more often observed in the amoxicillin group (4 patients) than in the groups of phytotherapy ( 2 patients) and multimodal therapy (1 patient). Along with that, ear infection, headache, nose bleeding and pruritus were observed in one patient in the phytotherapy group. Two mild adverse events were observed in group 2 (antibiotic therapy): allergic dermatitis (rash on lower extremities) and bitter taste in the mouth. The researchers classified these events as "possibly/probably caused by the drug under analysis". After the therapy period, nasal bleeding (2 patients ) was observed in groups of phytotherapy and multimodal therapy; emesis (1 patient) - in group 2. No severe adverse events were observed. All the adverse events terminated in the course of study.

Three patients withdrew from the study: one patient from group 2 - due to an adverse event (allergic dermatitis - scattered rash on lower extremities); one patent with PCT level $<0.25$ $\mathrm{ng} / \mathrm{ml}$ (group 1) - due to insufficient response to therapy after 3 therapy days (according to the researcher's estimates); one patient (group 3) - due to recall of the informed consent prior to the study drug intake onset.

According to the researcher's and parental estimates, tolerance of all the patients from group of phytotherapy and multimodal therapy and of $96.7 \%$ of the patients from the amoxicillin group to therapy was "good" and "very good". Tolerance to antibiotic therapy was classified as "average" and "poor" in two patients.

\section{DISCUSSION}

Phytotherapy (syrup characterized by a fixed combination of thyme herb and ivy leaf extracts), antibiotic therapy (amoxicillin) and multimodal therapy (herbal syrup and amoxicillin) had comparable safety profiles at acute bronchitis in children. The study demonstrated that phytopreparation use was not inferior to antibiotic therapy. Herbal syrup treatment (recommended dosage) for not more than 10 days was safe and well tolerated; according to the researcher's estimates, it was more effective than antibiotic therapy.

The study did not convincingly confirm the expected lower effect of antibiotic therapy in patients with low PCT, i.e. without clinical signs of bacterial infections, as compared to patients with high PCT. However, it ought to be mentioned that conclusiveness of this result is low due to a small number of patients with high PCT. PCT $<0.25 \mathrm{ng} / \mathrm{ml}$ was observed in most patients in this study; this fact confirmed the assumption that acute bronchitis is usually viral.

P. Little et al., who performed a double-blind placebo-controlled randomized clinical trial involving 2,061 adult patients from 12 European countries, analyzed risk/benefit ratio of amoxicillin for acute infectious diseases of lower airways as compared to placebo. The researchers observed little benefit of amoxicillin to patients with acute infections of lower airways without pneumonia and the association thereof with adverse side reactions [10]. This is confirmed by authors of a recent update of the Cochrane review on antibiotics for acute bronchitis: 15 studies involving 2,618 patients were analyzed [3]. According to the overall researchers' estimates, condition of the patients treated with antibiotics did not improve (6 studies, 891 patients). However, some of the patients treated with antibiotics recovered slightly faster. The review authors assume that the benefit of antibiotics is limited and emphasize the need in continuing search for alternative methods of resolving symptoms in patients with acute bronchitis due to potential side effects, self-limiting nature of the disease, high cost of antibiotics and increasing bacterial resistance to antibiotics. 


\section{CONCLUSION}

Results of this study demonstrate that phytotherapy is as effective as amoxicillin therapy. Evaluation of parameters "time to the event" confirms that phytotherapy is indicated in all cases: the most beneficial therapy for patients with acute virus bronchitis is pure herbal drug treatment, whereas multimodal therapy (phytopreparations + antibiotics) is especially effective in patients with acute bacterial bronchitis. Use of syrups characterized by a fixed combination of thyme herb and ivy leaf extracts resulted in fewer adverse events than antibiotic therapy, i.e. phytotherapy boasts a better risk/benefit ratio. Moreover, effectiveness and safety of this phytopreparation was demonstrated in a double-blind clinical study of adults by way of comparison with a placebo [11] and in a post-authorization study involving children [12]. Summarizing results of these studies and the data we managed to obtain, we may conclude that syrup Bronchipret is an effective and a well tolerated alternative antibiotics for acute bronchitis in children.

\section{FINANCIAL DISCLOSURE}

Multicenter study (EURO-PCT) was sponsored by the company Bionorica SE, Germany.

\section{REFERENCES}

1. Kronenberg R.S., Griffith D.E. Bronchitis and acute febrile tracheobronchitis. In: Respiratory infections. A scientific basis for management. Ed. Niederman, Sarosis, Glassroth. New York: W.B. Saunders Company. 1994. P. 91-102.

2. Balabanova Y., Fedorin I., Kuznetsov S. et al. Antimicrobial prescribing patterns for respiratory diseases including tuberculosis in Russia: a possible role in drug resistance? JAC. 2004; 54 (3): 673-9.

3. Smith S.M., Fahey T., Smucny J., Becker L.A. Antibiotics for acute bronchitis. Cochrane Database of Systematic Reviews. 2004; Issue 4. Art. №: DC000245. Doi: 10.1002/14651858.CD000245.pub2.

4. Nyquist A.C., Gonzales R., Steiner J.F., Sande M.A. Antibiotic prescribing for children with colds, upper respiratory tract infections, and bronchitis. JAMA. 1998; 279 (11): 875-7.

5. Stratchounski L.S., Andreeva I.V., Ratchina S.A. et al. The inventory of antibiotics in Russian home medicine cabinets. Clin Infect Dis. 2003; 37 (4): 498505.

6. Hersh A.L., Shapiro D.J., Pavia A.T. et al. Antibiotic Prescribing in Ambulatory Pediatrics in the United States. Pediatrics. 2011; 128: 1053-1061.

7. Hanberger H., Diekema D., Fluit A. et al. Surveillance of antibiotic resistance in European ICUs. J Hosp Infect. 2001; 48 (3): 161-76.

8. Shann F., Hart K., Thomas D. Acute lower respiratory tract infections in children: possible criteria for selection of patients for antibiotic therapy and hospital admission. 1984. Bull World Health Organ. 2003; 81 (4): 301-5.

9. Christ-Crain M., Jaccard-Stolz D., Bingisser R. et al. Effect of procalcitonin-guided treatment on antibiotic use and outcome in lower respiratory tract infections: cluster-randomised, single-blinded intervention trial. Lancet. 2004; 363 (9409): 600-7.

10. Little P., Stuart B., Moore M. et al. Amoxicillin for acute lower-respiratory-tract infection in primary care when pneumonia is not suspected: a 12-country, randomised, placebocontrolled trial. Lancet Infect Dis. 2013; 13 (2): 123-9.

11. Kemmerich B., Eberhardt R., Stammer H. Efficacy and tolerability of a fluid extract combination of thyme herb and ivy leaves and matched placebo in adults suffering from acute bronchitis with productive cough. A prospective, double-blind, placebo-controlled clinical trial. Arzneimittelforschung. 2006; 56 (9): 652-660. 
12. Marzian O. Treatment of acute bronchitis in children and adolescents. Non-interventional postmarketing surveillance study confirms the benefit and safety of a syrup made of extracts from thyme and ivy leaves [Article in German]. MMW Fortschr Med. 2007; 149 (11): 69-74. 
Table 1. Demographic and initial parameters (PP)

\begin{tabular}{|c|c|c|c|c|}
\hline Variable & $\begin{array}{l}\text { Statistical } \\
\text { parameter }\end{array}$ & $\begin{array}{l}\text { Phytotherapy } \\
(n=51)\end{array}$ & $\begin{array}{l}\text { Antibiotic therapy } \\
\qquad(\mathrm{n}=54)\end{array}$ & $\begin{array}{c}\text { Multimodal } \\
\text { therapy } \\
(n=53)\end{array}$ \\
\hline $\begin{array}{l}\text { Race } \\
\text { Caucasian } \\
\text { Other }\end{array}$ & $\begin{array}{l}\mathrm{n}(\%) \\
\mathrm{n}(\%)\end{array}$ & $\begin{array}{c}51(100.0) \\
0(0.0)\end{array}$ & $\begin{array}{c}54(100.0) \\
0(0.0)\end{array}$ & $\begin{array}{c}53(100.0) \\
0(0.0)\end{array}$ \\
\hline $\begin{array}{l}\text { Sex } \\
\text { Male } \\
\text { Female } \\
\end{array}$ & $\begin{array}{l}\mathrm{n}(\%) \\
\mathrm{n}(\%)\end{array}$ & $\begin{array}{l}33(64.7) \\
18(35.3) \\
\end{array}$ & $\begin{array}{l}26(48.1) \\
28(51.9) \\
\end{array}$ & $\begin{array}{l}32(60.4) \\
21(39.6) \\
\end{array}$ \\
\hline $\begin{array}{l}\text { Age } \\
2-5 \text { years } \\
6 \text { years }\end{array}$ & $\begin{array}{l}\mathrm{n}(\%) \\
\mathrm{n}(\%)\end{array}$ & $\begin{array}{c}44(86.3) \\
7(13.7) \\
\end{array}$ & $\begin{array}{c}50(92.6) \\
4(7.4)\end{array}$ & $\begin{array}{c}44(83.0) \\
9(17.0)\end{array}$ \\
\hline $\begin{array}{l}\text { Age (in } \\
\text { years) }\end{array}$ & $\begin{array}{l}\text { Mean } \pm \text { SD } \\
\text { min-max }\end{array}$ & $\begin{array}{c}3.7 \pm 1.5 \\
2.0-6.0\end{array}$ & $\begin{array}{c}3.6 \pm 1.4 \\
2.0-6.0\end{array}$ & $\begin{array}{c}3.6 \pm 1.4 \\
2.0-6.0\end{array}$ \\
\hline $\begin{array}{l}\text { Weight } \\
\text { (in kg) }\end{array}$ & $\begin{array}{l}\text { Mean } \pm \text { SD } \\
\text { min-max }\end{array}$ & $\begin{array}{l}17.2 \pm 3.8 \\
12.0-28.0\end{array}$ & $\begin{array}{c}16.0 \pm 3.1 \\
11.5-23.8\end{array}$ & $\begin{array}{l}17.1 \pm 3.8 \\
11.7-28.1\end{array}$ \\
\hline $\begin{array}{l}\text { Height } \\
\text { (in cm) }\end{array}$ & $\begin{array}{l}\text { Mean } \pm \text { SD } \\
\text { min-max }\end{array}$ & $\begin{array}{c}103.3 \pm 11.1 \\
84.0-130.0\end{array}$ & $\begin{array}{l}100.5 \pm 9.8 \\
81.0-119.0\end{array}$ & $\begin{array}{c}103.2 \pm 10.4 \\
82.0-131.0\end{array}$ \\
\hline
\end{tabular}

Note. $\mathrm{PP}$ - per protocol population, $\mathrm{SD}-$ standard deviation.

Table 2. Therapy groups

\begin{tabular}{|l|l|}
\hline \multicolumn{1}{|c|}{ Therapy groups } & \multicolumn{1}{c|}{ Prescribed therapy } \\
\hline Phytotherapy* & $\begin{array}{l}\text { Syrup Bronchipret }- \text { fixed combination of thyme herb and ivy leaf extracts } \\
\text { (Bionorica CE, Germany): } \\
\text { 2-5 years of age }-3.2 \mathrm{ml} \text {; } \\
\text { 6 years of age }-4.3 \mathrm{ml} \text { TID per os }\end{array}$ \\
\hline $\begin{array}{l}\text { Antibiotic } \\
\text { therapy* }\end{array}$ & $\begin{array}{l}\text { Amoxicillin, granules for per os suspension (Chemopharm, Serbia): } \\
\text { 2-5 years of age }-2.5 \mathrm{ml}(125 \mathrm{mg}) ; \\
\text { 6 years of age }-5 \mathrm{ml}(250 \mathrm{mg}) \mathrm{TID}\end{array}$ \\
\hline $\begin{array}{l}\text { Multimodal } \\
\text { therapy }\end{array}$ & $\begin{array}{l}\text { Syrup Bronchipret: } \\
\text { 2-5 years of age }-3.2 \mathrm{ml} \text {; } \\
\text { 6 years of age }-4.3 \mathrm{ml} \text { TID per os } \\
\text { + amoxicillin, granules for per os suspension: } \\
\text { 2-5 years of age }-2.5 \mathrm{ml}(125 \mathrm{mg}) ; \\
\text { 6 years of age }-5 \mathrm{ml}(250 \mathrm{mg}) \mathrm{TID}\end{array}$ \\
\hline
\end{tabular}

Note. The study employed a double-dummy technique: along with the active drug form appropriate placebos were additionally used in groups of phytotherapy and antibiotic therapy. Period of use of each drug - 10 days.

Table 3. Distribution of PP patients

\begin{tabular}{|l|c|c|c|c|c|c|}
\hline \multirow{2}{*}{ Subgroup } & \multicolumn{2}{|c|}{ Phytotherapy, n } & \multicolumn{2}{c|}{ Antibiotic therapy, n } & \multicolumn{2}{c|}{ Multimodal therapy, n } \\
\cline { 2 - 7 } & Total & Significant & Total & Significant & Total & Significant \\
\hline All patients (PP) & 51 & 49 & 54 & 49 & 53 & 50 \\
\hline Low PCT* & 46 & 44 & 52 & 47 & 51 & 48 \\
\hline High PCT** & 5 & 5 & 2 & 2 & 2 & 2 \\
\hline
\end{tabular}

Note. $*$ PCT $<0.25 \mathrm{ng} / \mathrm{ml}$; ** PCT $\geq 0.25 \mathrm{ng} / \mathrm{ml}$. PP - per protocol population, PCT procalcitonin. 
Table 4. Effectiveness variables: time to even (median time in days)

\begin{tabular}{|l|l|c|c|c|}
\hline \multicolumn{1}{|c|}{ The first-time event } & Subgroup & Phytotherapy & $\begin{array}{c}\text { Antibiotic } \\
\text { therapy }\end{array}$ & $\begin{array}{c}\text { Multimodal } \\
\text { therapy }\end{array}$ \\
\hline \multirow{4}{*}{ Normal everyday lifestyle } & PP & 5.0 & 5.0 & 5.0 \\
\cline { 2 - 5 } & Low PCT & 4.0 & 5.0 & 5.0 \\
\cline { 2 - 5 } & High PCT & 7.0 & 8.0 & 4.5 \\
\hline \multirow{2}{*}{$\begin{array}{l}\text { No disturbed falling } \\
\text { asleep }\end{array}$} & PP & 3.0 & 3.0 & 3.5 \\
\cline { 2 - 5 } & Low PCT & 3.0 & 3.0 & 3.5 \\
\cline { 2 - 5 } & High PCT & 4.0 & 4.5 & 3.0 \\
\hline \multirow{2}{*}{$\begin{array}{l}\text { No nocturnal sleep } \\
\text { disturbances }\end{array}$} & PP & 5.0 & 4.0 & 4.0 \\
\cline { 2 - 5 } & Low PCT & 4.0 & 4.0 & 4.0 \\
\cline { 2 - 5 } & High PCT & 7.0 & 6.0 & 2.5 \\
\hline \multirow{2}{*}{ No nocturnal cough } & PP & 5.0 & 6.0 & 6.0 \\
\cline { 2 - 5 } & Low PCT & 4.0 & 6.0 & 6.0 \\
\cline { 2 - 5 } & High PCT & 7.0 & 7.0 & 5.5 \\
\hline
\end{tabular}

Note. $\mathrm{PP}$ - per protocol population, $\mathrm{PCT}-$ procalcitonin.

Pic. 1. Study design

Терапия 10 дней*

Наблюдение 18 дней

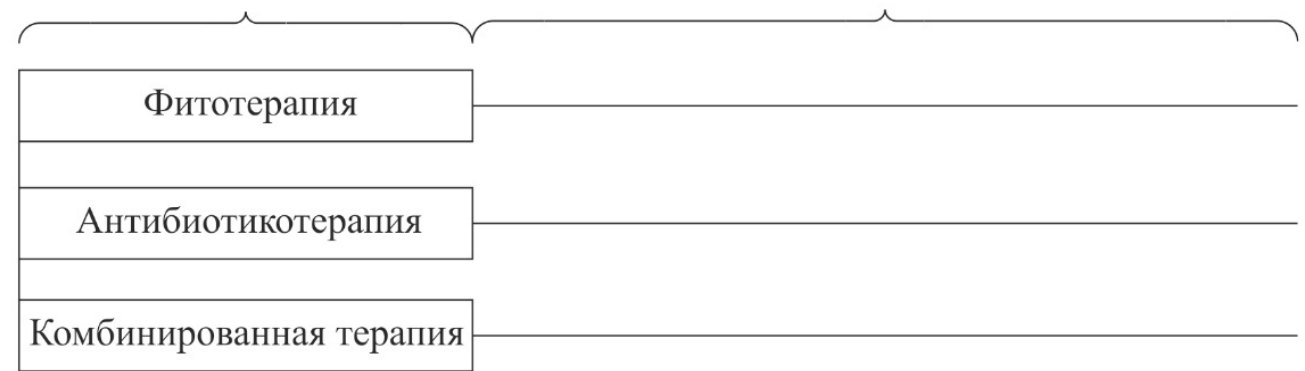

\begin{tabular}{ccccc} 
Визиты & 1 & $2_{\text {контакт }}^{\text {reльй }}$ & 3 & 4 \\
\hline Дни & 0 & $2-3$ & 7 & 10 \\
& $\uparrow$ & & &
\end{tabular}

Скрининг

5 телефонный

10

28

Рандомизация

Окончание

иследования

*Терапия была прекращена через 7 дней, если пациент выздоровел, по мнению исследователя

\begin{tabular}{|c|c|}
\hline Терапия 10 дней & Therapy (10 days) \\
\hline Наблюдение 18 дней & Observation (18 days) \\
\hline Фитотерапия & Phytotherapy \\
\hline Антибиотикотерапия & Antibiotic therapy \\
\hline Комбинированная терапия & Multimodal therapy \\
\hline Bизиты & Visits \\
\hline Дни & Days \\
\hline Телефонный контакт & Telephone call \\
\hline Скрининг, Рандомизация & Screening, Randomization \\
\hline Окончание исследования & Study end \\
\hline $\begin{array}{l}\text { Терапия была прекращеена через } 7 \text { дней, если } \\
\text { пациент выздоровел, по мнению исследователя }\end{array}$ & $\begin{array}{l}\text { Therapy would be discontinued if the child } \\
\text { recovered (according to the researcher's } \\
\text { estimates) }\end{array}$ \\
\hline
\end{tabular}


Pic. 2. Distribution of patients

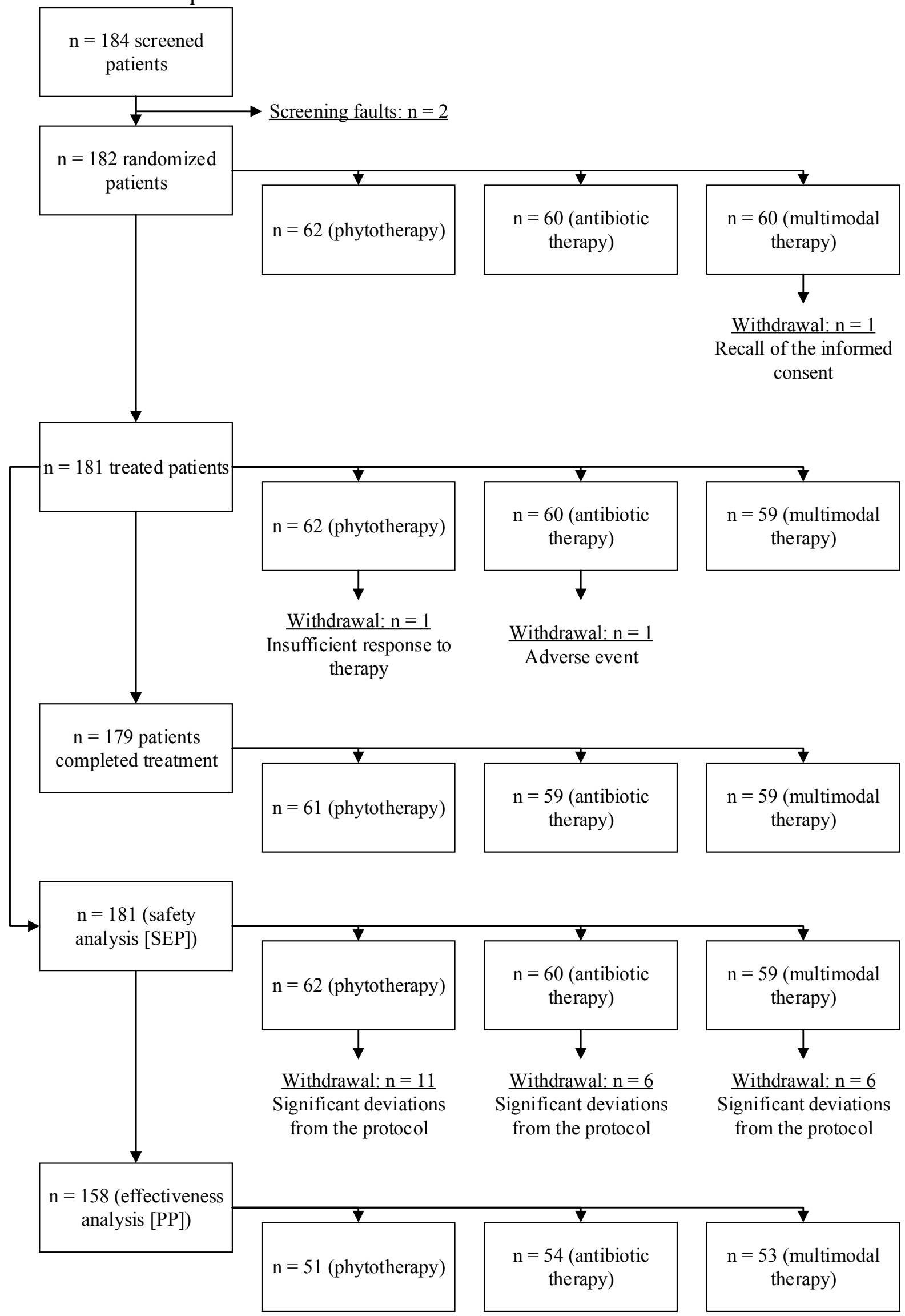


SEP (safety evaluable population) - patients who received at least one drug dose and who provided sufficient safety data. PP (per protocol population) - patients who completed the study without significant deviations from the protocol.

Pic. 3. Phytotherapy non-inferiority to antibiotic therapy regarding the share of patients responding to therapy

\begin{tabular}{|c|c|c|c|c|}
\hline & & $\begin{array}{r}\text { Битотера } \\
\text { чем } \\
\end{array}$ & $\begin{array}{l}\text { ия не менее эффективна, } \\
\text { нтибиотикотерапия }\end{array}$ & \\
\hline & $\begin{array}{r}\text { Граница не } \\
\text { эффекти }\end{array}$ & :ньшей & & \\
\hline $\begin{array}{l}\mathrm{PCT}<0,25 \text { нг/мл } \\
(\mathrm{n}=98)\end{array}$ & $\begin{array}{l}\Delta=-0,25 \\
\text { Ди }[-11,19 ; 10,69]\end{array}$ & $\longmapsto$ & & \\
\hline $\begin{array}{l}\text { Все пациенты } \\
(\mathrm{n}=105)\end{array}$ & $\begin{array}{l}\Delta=-0,11 \\
\text { ДИ }[-10,48 ; 10,26]\end{array}$ & $\longmapsto$ & -1 & \\
\hline & -15 & & $\begin{array}{c}0 \\
\text { ичие терапии [\%] }\end{array}$ & \\
\hline $\begin{array}{l}\text { iя не мене } \\
\text { отерапия }\end{array}$ & е эффективна & чем & $\begin{array}{l}\text { Phytotherapy is as } \\
\text { antibiotic therapy }\end{array}$ & effective as \\
\hline еньшей эфффек & пивности & & Non-inferiority limit & \\
\hline & & & $n g / m l$ & \\
\hline & & & $C I$ & \\
\hline$b l$ & & & All patients & \\
\hline onuu & & & Therapy difference & \\
\hline
\end{tabular}

Note. Subgroup of patients with PCT $<0.25 \mathrm{ng} / \mathrm{ml}$ and all patients (per protocol population) at the $7^{\text {th }}$ therapy day.

PCT - procalcitonin, CI - confidence interval. 